\title{
PHYSIOLOGICAL AND YIELD RESPONSES OF SOME SELECTED RAPESEED/ MUSTARD GENOTYPES TO HIGH TEMPERATURE STRESS
}

\author{
Faruque Ahmed ${ }^{* 1}$, I.M. Ahmed ${ }^{1}$, N. Mokarroma ${ }^{1}$ F. Begum ${ }^{2}$ and A. Jahan ${ }^{3}$ \\ ${ }^{1}$ Plant Physiology Division, BARI, Gazipur-1701 \\ ${ }^{2}$ Oilseed Research center, BARI, Gazipur-1701 \\ ${ }^{3}$ Department of Soil Science, SAU, Dhaka-1207 \\ *Corresponding E-mail: faruquebari@gmail.com \\ (Received: 24 April 2019, Accepted: 24 October 2019)
}

Keywords: High temperature, stress, physiology, Rapeseed/mustard, genotypes, yield

\begin{abstract}
A pot experiment was conducted with five selected rapeseed/mustard genotypes (BJDH-11, BJDH-12, BJDH-20, BARI Sarisha-14, and BARI Sarisha-16) under two sowing dates (November 20 and December 20) for evaluating their responses to sowing date induced high temperature stress during rabi season of 2017-18. Sowing dates induced temperature variability showed remarkable changes in pheonlogy, leaf area, leaf chlorophyll content, dry matter production and seed yield. Although December 20 sown crop received lower temperatures (minimum 9.8 to 13.2 and maximum 22.6 to $27^{\circ} \mathrm{C}$ ) than November 20 sown crop (minimum 14.8 to 16.4 and maximum 21 to $27.2^{\circ} \mathrm{C}$ ) at flowering but reverse was found at grain development stage. Grain development stage of November 20sown crop received lower temperatures (minimum 8.2 to 13.2 and maximum 24.1 to $27{ }^{\circ} \mathrm{C}$ ) while December 20 sown crop received higher temperatures at grain development stage (minimum 8.2 to 18 and maximum 22.6 to $32.5^{\circ} \mathrm{C}$ ). As a result December 20 sown crop matured earlier (6 to 9 days) than November 20 sown crop. Leaf area/plant was higher in December 20 sown crops compared to November 20 sown but total dry matter production was more or less same in both the sowing dates. Leaf chlorophyll content did not show any remarkable variation due to variation in sowing dates. However, antioxidant activity like Catalyse (CAT), Peroxidase (POD) Ascorbate peroxidase (APX) and Malondial dehyde (MDA) were found higher in December 20 sown crops than that of November 20sown. Higher activity of APX, POD and CAT with lower activity of MDA indicates comparatively high temperature tolerant genotype. Among the genotypes APX, POD and CAT activity were found higher with lower activity of MDA in BJDH-11 and BJDH-20 and these genotypes also gave higher yield than others. On the basis of growth parameters, antioxidant activity and seed yield of genotype BJDH-11 and BJDH-20 could be select as terminal high temperature tolerance genotypes.
\end{abstract}

\section{Introduction}

High temperature stress is the most important abiotic stress affecting plant productivity around the world (Hall, 1992). The rising atmospheric $\mathrm{CO}_{2}$ and temperature are the two important factors of climate change which are likely to impact agriculture and food security across the globe. Despite some projected increase in photosynthesis due to higher atmospheric $\mathrm{CO}_{2}$, increased temperature results in reduced productivity (Wassmann et al., 2009). The global average air temperature is expected to rise by 1.8 to $4^{0} \mathrm{C}$ by the end of this century. The Rabi season temperature is expected to increase more than the kharif season 
Ahmed et al.

(Aggarwal and Mall, 2002). Rapeseed/mustard constitute an important source of edible oiling Bangladesh. It grows under diverse agro-ecological situations such as timely/late sown, rainfed/irrigated, sole or mixed crop with cereals (wheat, barley etc.) and rabi (October-March) pulses (chickpea, lentil etc.), where high temperature is the main constraint not only at germination but also at grain filling stage. Generally, plants respond to high temperature stress through developmental, biochemical and physiological changes and the type of the observed response depends on several factors such as stress intensity, stress duration and genotype (Moradshahi et al., 2004). Flowering and grain filling are the most sensitive stages for temperature stress damage probably due to vulnerability during pollen and grain development, anthesis and fertilization leading to reduce crop yield (Hall, 1992). High temperature in Brassica enhanced plant development and caused flower abortion and poor grain filling with appreciable loss in seed yield. A rise of $3^{\circ} \mathrm{C}$ in maximum daily temperature $\left(21-24^{\circ} \mathrm{C}\right)$ during flowering and grain filling caused a decline of $430 \mathrm{~kg} / \mathrm{ha}$ in canola seed yield (Singh et al., 2014). Therefore, improving seed yield of rapeseed- mustard under late sown conditions is main challenge for rapeseed mustard research. Hence there is need to develop terminal heat tolerant genotype on the basis of desirable physiological traits.

\section{Materials and Methods}

A pot experiment was conducted at the research field of Plant physiology Division, BARI Gazipur during rabi season of 2017-18. Five selected genotypes namely: BJDH-11, BJDH-12, BJDH-20, BARI Sarisha-14 (BARI_14), and BARI Sarisha-16(BARI-16) were used as test crop under two sowing dates November 20 and December 20. The experiment was laid out in randomized complete block design with 10 replications. Plastic pot (top dia: $25 \mathrm{~cm}$, bottom dia: 18 $\mathrm{cm}$ and height $25 \mathrm{~cm} ; 12 \mathrm{~kg}$ soil) was filled up with soil and cowdung (4:1). Ten seeds were sown in each pot according to treatments. Fertilizers were applied 100-30-80-20-3-1 kg/ha NPKSZnB. Half of $\mathrm{N}$ and all other fertilizers were applied as basal and remaining $\mathrm{N}$ was applied at 20 DAS. Irrigation was done as and when required for maintaining adequate soil moisture. After emergence plants were thinned to three plants in each pot. Plants from three pots were sampled for leaf area and dry matter measurement at different growth stages. Sampled plants were separated into leaf, stem and siliqua. Leaf area was measured by an automatic area meter (LI-3100 C; LI-Cor, USA). Plant parts were dried in an oven for 72 hours at $70^{\circ} \mathrm{C}$ and dry weight was recorded. At harvest yield and yield components data were collected from three pots and analyzed statistically and mean separation was done by LSD test at 5\% level of significance.

\section{Chlorophyll estimation}

Leaves ( $3^{\text {rd }}$ leaf from top)of each genotype were collected on 55 DAS for Chlorophyll measurement. Leaves were properly cut into small pieces and weighed $0.5 \mathrm{~g}$ and were taken for chlorophyll estimation. Chlorophyll a, chlorophyll b and total chlorophyll were estimated following Arnon's method (Arnon, 1949). The absorbance of the solution was read at 645 and $663 \mathrm{~nm}$ for Chlorophyll a, Chlorophyll b and total chlorophyll.

Calculation:

Chlorophyll a $\left(\mathrm{mg} \mathrm{g}^{-1}\right)=\{12.7$ (D663) - 2.69 (D645) $\} \mathrm{Y} \mathrm{V} /(1000 \mathrm{\Psi} \mathrm{w})$

Chlorophyll b $\left(\mathrm{mg} \mathrm{g}^{-1}\right)=\{22.9$ (D645) -4.68 (D663) $\}$ Ч V/(1000 Ч w)

Total chlorophyll $\left(\mathrm{mg} \mathrm{g}^{-1}\right)=20.2(\mathrm{D} 645)+8.02(\mathrm{D} 663) \mathrm{Y} \mathrm{V} /(1000 \mathrm{\varphi} \mathrm{w})$

Where $\mathrm{D}=$ optical density

$\mathrm{V}=$ final volume of $80 \%$ acetone $(\mathrm{ml})$ 
49

$\mathrm{w}=$ dry weight of sample taken $(\mathrm{g})$

Bio-Chemical analysis

Leaf samples ( $3^{\text {rd }}$ leaf from top) were collected on 55 DAS for antioxidant enzyme like Catalyse (CAT), Ascorbate peroxidase (APX) and Peroxidase (POD) and malondialdehyde (MDA) determination.

\section{Enzyme Extraction and Assays}

Using a pre-cooled mortar and pestle, $0.5 \mathrm{~g}$ of leaf tissue was homogenized in $1 \mathrm{ml}$ of $50 \mathrm{~m} \mathrm{M}$ ice-cold K-phosphate buffer $(\mathrm{pH} \mathrm{7.0)}$ containing $100 \mathrm{~m} \mathrm{MKCl}$, $1 \mathrm{~m}$ Mascorbate, $5 \mathrm{~m}$ M $\beta$-mercaptoethanol, and $10 \%(\mathrm{w} / \mathrm{v})$ glycerol. The homogenates were centrifuged at $11,5004 \mathrm{~g}$ for $10 \mathrm{~min}$, and the supernatants were used for determination of enzyme activity. All procedures were performed at ${ }^{\circ} \mathrm{C}$ to $4{ }^{\circ} \mathrm{C}$.

\section{Determination of Protein}

The protein concentration of each sample was determined following the method of Bradford (1976) using BSA as a protein standard where 5, 10, 15, 20, 25 $\mu \mathrm{g}^{-1} \mathrm{l}^{-1}$ protein concentrations were used to prepare standard curve.

Peroxidase (POD, EC 1.11.1.7): POD activity was estimated according to Hemeda and Klein (1990). The reaction mixture contained $25 \mathrm{~m} \mathrm{M} \mathrm{K-P}$ buffer ( $\mathrm{pH}$ 7.0), $0.05 \%$ guaiacol, $10 \mathrm{mM} \mathrm{H}_{2} \mathrm{O}_{2}$ and enzyme. Activity was determined by the increase in absorbance at $470 \mathrm{~nm}$ due to guaiacol oxidation for $1 \mathrm{~min}$ using extinction coefficient of $26.6 \mathrm{mM}^{-1} \mathrm{~cm}^{-1}$.

Catalase (CAT, EC: 1.11.1.6): CAT activity was measured according to the method of Hossain et al. (2010) by monitoring the decrease of absorbance at $240 \mathrm{~nm}$ for $1 \mathrm{~min}$ caused by the decomposition of $\mathrm{H}_{2} \mathrm{O}_{2}$. The reaction mixture contained $50 \mathrm{~m} \mathrm{M} \mathrm{K-phosphate} \mathrm{buffer} \mathrm{(} \mathrm{pH}$ 7.0), $15 \mathrm{~m} \mathrm{M} \mathrm{H} \mathrm{H}_{2}$, and enzyme solution in a final volume of $0.7 \mathrm{ml}$. The reaction was initiated with enzyme extract, and the activity was calculated using the extinction coefficient of 39.4 $\mathrm{M}^{-1} \mathrm{~cm}^{-1}$.

Ascorbate peroxidase (APX, EC: 1.11.1.11) activity was assayed following the method of Nakano and Asada (1981). The reaction buffer solution contained 50 $m$ M K-phosphate buffer ( $\mathrm{pH}$ 7.0), $0.5 \mathrm{~m}$ MAsc, $0.1 \mathrm{~m} \quad \mathrm{M} \mathrm{H}_{2} \mathrm{O}_{2}, 0.1 \mathrm{~m}$ MEDTA, and enzyme extract in a final volume of $0.7 \mathrm{ml}$. The reaction was started by the addition of $\mathrm{H}_{2} \mathrm{O}_{2}$, and the activity was measured by observing the decrease in absorbance at $290 \mathrm{~nm}$ for $1 \mathrm{~min}$ using an extinction coefficient of $2.8 \mathrm{mM}^{-1} \mathrm{~cm}^{-1}$.

\section{Lipid peroxidation}

The level of lipid peroxidation in plant tissues was expressed as 2-thiobarbituric acid (TBA) reactive metabolites, mainly malondialdehyde (MDA), and was determined according to Hodges et al. (1999). Fresh samples (leaves) of around $0.5 \mathrm{~g}$ were homogenizedin $4.0 \mathrm{ml}$ of $1 \%$ trichloroacetic acid (TCA) solution and centrifuged at $10,0004 \mathrm{~g}$ for $10 \mathrm{~min}$. The supernatant was added to $1 \mathrm{ml} 0.5 \%$ $(\mathrm{w} / \mathrm{v})$ TBA made in 20\% TCA. The mixture was heated in boiling water for30 min, and the reaction was stopped by placing the tubes in anice bath. The samples were centrifuged at $10,0004 \mathrm{~g}$ for $10 \mathrm{~min}$, and the absorbance of the supernatant was recorded at $532 \mathrm{~nm}$. Correction of non-specific turbidity was made by subtracting the absorbance value read at $600 \mathrm{~nm}$. The level of lipid per-oxidation was expressed as $\mathrm{nmol} \mathrm{g}^{-1}$ fresh weight, with a molar extinction coefficient of $0.155 \mathrm{mMcm}^{-1}$. 


\section{Phenology}

\section{Results and Discussion}

There was variability in days required for emergence of the genotypes in November 20 sown; BJDH-11 and BARI Sarisha-14 took five days while others took 6 days for emergence. But in December 20 sowing all the genotypes took four days for emergence. Generally December 20 sowing took less days for emergence compared to November 20 sown due to higher temperature at sowing. Flowering was delayed in 20 December sown than November 20 sown in all the genotypes except BARI Sarisha-14 which took same days for flowering in both the sowing dates. November 20 sown genotypes flowered within 28-34 days while that was 28-37 days for December 20 sown. Among the genotypes early flowering was observed in BARI Sarisha-14. In December 20 sown, all the genotypes matured earlier than November 20 sowing (Fig. 3).
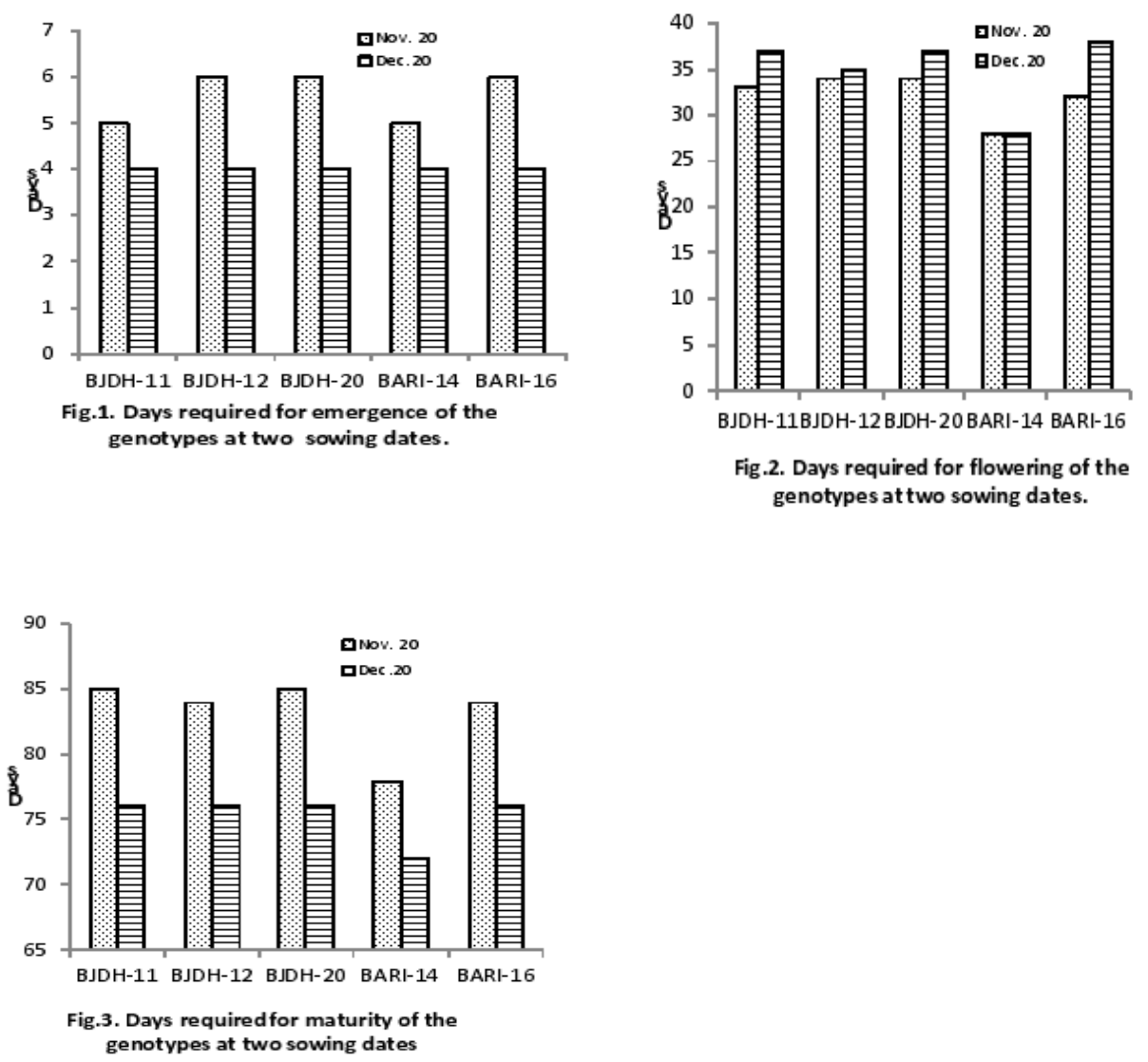

\section{Temperature regime}

Fig. 4 shows the air temperatures (maximum and minimum) during crop growing periods. On November 20 sowing crop emerged when maximum and minimum temperatures were $>30$ and $>15^{\circ} \mathrm{C}$ but on December 20 sown crop emerged when those were $<30$ and $<15^{\circ} \mathrm{C}$, as a result December sown took more days for emergence than November sown. November 20 sowing crop flowered when maximum temperatures were around $26-27^{\circ} \mathrm{C}$ and minimum temperature were around $13-15^{\circ} \mathrm{C}$ but at flowering December 20 sowncrop received $24-26^{\circ} \mathrm{C}$ as maximum and $9-12^{\circ} \mathrm{C}$ as minimum temperatures. After flowering November 
51

20sowncrop received lower temperatures than December 20 sown crop up to harvest as a result December 20 sown crop matured earlier than November 20 sown crop.

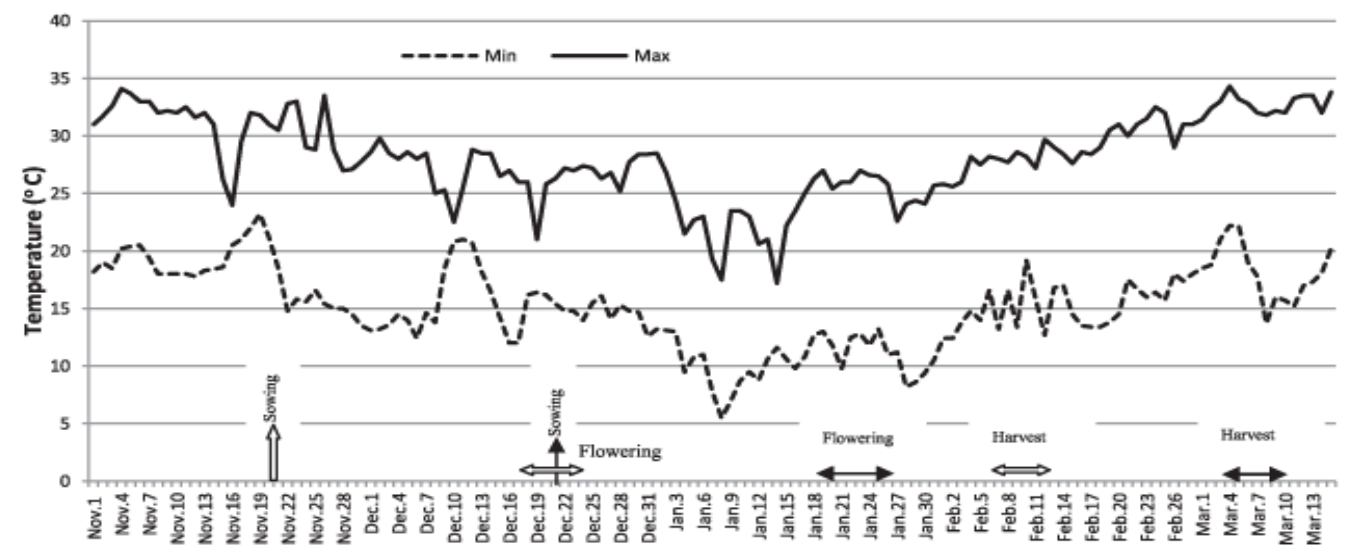

\section{Leaf area/plant F.g.4. Daily maximum and minimum temperatures during crop growing periods}

Fig. 5 and Fig.6 shows leaf area/plant of the genotypes at November 20 and December 20sown. In both the sowing dates, leaf area increased up to 50 days after sowing; there after it decreased due to leaf senescence. In November 20 sown maximum leaf area was observed in BJDH-11 and BARI Sarisha-16 throughout the growing periods followed by BJDH-12 and BJDH-20. Lower leaf area/plant was observed in BARI Sarisha-14 throughout the growing season. In December 20 sowing maximum leaf area was observed in BARI-16 (BARI Sarisha-16) and BJDH-11 at 50 DAS followed by BJDH-12 and BJDH-20 and minimum in BARI Sarisha-14.

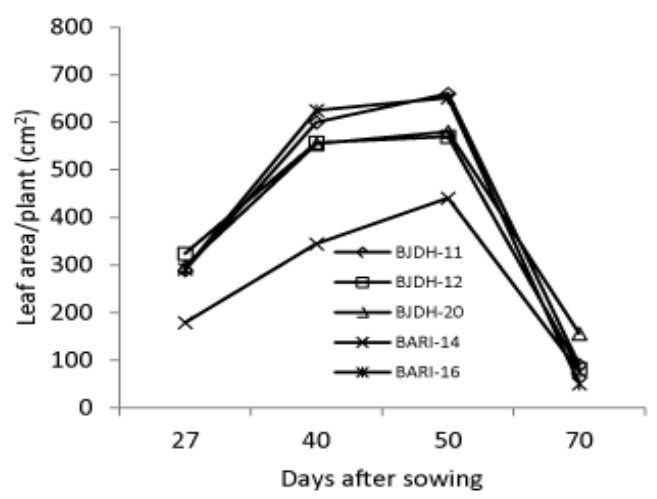

Fig. 5. Leaf area of the genotypes at November 20 sowing

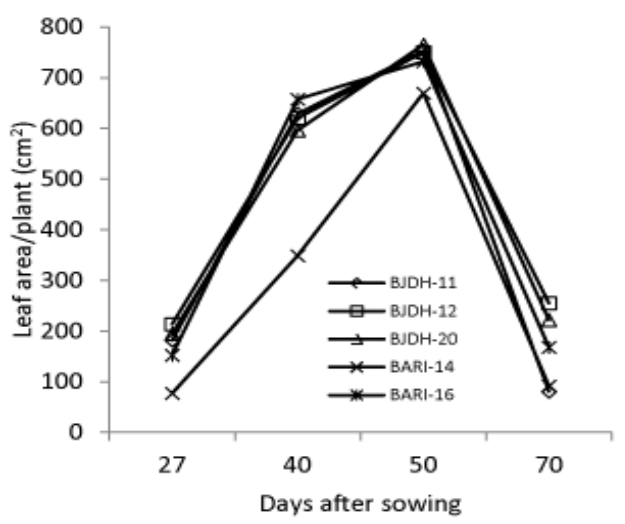

Fig. 6. Leaf area of the genotypes at December 20 sowing

\section{Total dry matter (TDM)}

TDM in both the sowing dates increased up to harvest (Fig. 7 and 8). At both the sowing dates higher TDM was observed in BJDH-11, BJDH-12, BJDH-20 compared to others and the lowest TDM was observed in BARI Sarisha-14. TDM production was almost similar at both the sowing dates.
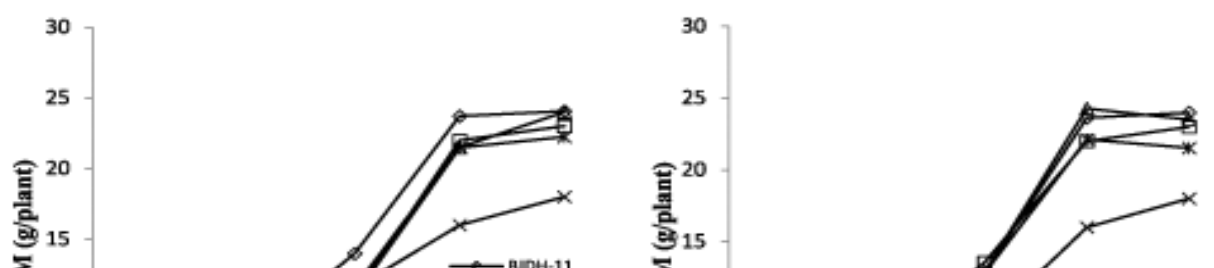


\section{Antioxidant activity}

APX activity increased due to higher temperature stress in December 20 sowing compared to November 20 sowing in all the genotypes (Fig.9). Maximum APX activity was found in BARI Sarisha-14 followed by BARI Sarisha-16, BJDH-20 and BJDH-11 and the lowest in BJDH-12.

Higher POD activity was observed in BJDH-11 followed by BJDH-20 and the minimum was found in BARI Sarisha-16 (Fig.10). APX and POD enzyme were increased in tolerant genotype but decreased in susceptible genotype (Babita Rani et al., 2016).

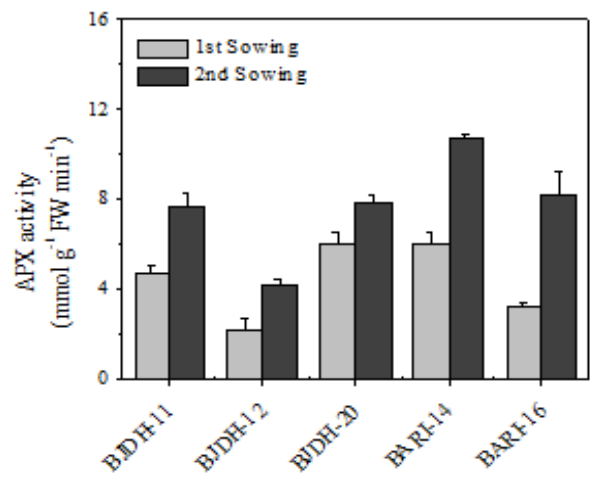

Fig. 9. APX activity of the genotypes at Nov 20

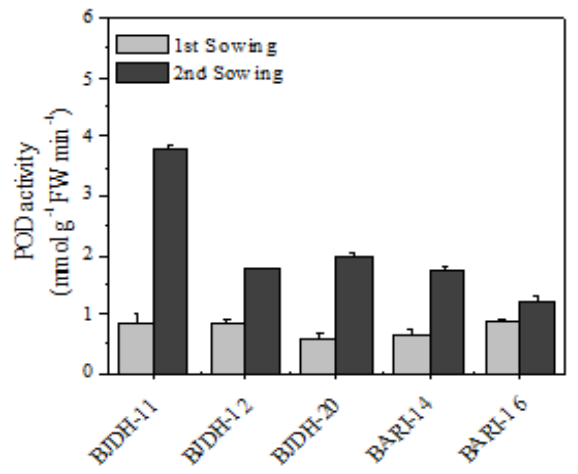

Fig. 10. PODactivity of the genotypes atNov 20 and

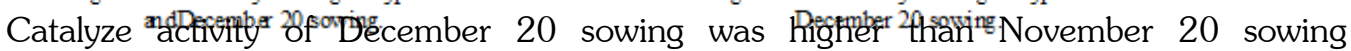
irrespective of genotypes (Fig.11). Highest CAT activity was found in BJDH-20 followed by BARI Sarisha-16 and the lower CAT activity was found in BJDH-12 in both the sowing dates. Soengas (2018) reported higher CAT activity in Brassica under heat stress than under control condition. The enzymatic activity of CAT was significantly higher under heat than under control conditions for both sown crops. The activities of superoxide dismutase (SOD), catalase (CAT) and peroxidase (POX) and the level of prolineexhibited increases in response to heat stress application (Hayat et al., 2009). Heat stress induces oxidative stress. For example, generation and reaction of activated oxygen species (AOS), which causes the autocatalytic per-oxidation of membrane lipids and pigments subsequently leads to membrane permeability and modification of its functions (Xu et al., 2006).

Highest MDA activity was observed in BARI Sarisha-14, BJDH-12 and BARI Sarisha-16 and the lowest MDA activity was found in BJDH-11 and BJDH-20 
53

(Fig.12). Lower MDA was reported in tolerant genotypes of Brassica juncea compared to susceptible genotypes by Wilson et al. (2014).

\section{Leaf chlorophyll content}

Table 1 shows leaf chlorophyll content at pre-flowering stage of the genotypes at two sowing dates. Chlorophyll content of the genotypes at November 20 sowing and December 20 sowing did not show any remarkable differences although December 20 sowing showed comparatively higher values.

Table 1. Leaf chlorophyll content in rapeseed-mustard genotypes at pre-flowering stage

\begin{tabular}{|l|l|l|l|l|l|l|}
\hline & \multicolumn{3}{|l|}{ Nov-20 Sowing $(\mathrm{mg} / \mathrm{g}$ FW) } & \multicolumn{3}{l|}{ Dec-20 Sowing (m/g FW) } \\
\hline & Chl a & C hl b & Chl $(\mathrm{a}+\mathrm{b})$ & Chl a & $\mathrm{C} \mathrm{hl} \mathrm{b}$ & Chl $(\mathrm{a}+\mathrm{b})$ \\
\hline BJDH-11 & 0.701424 & 0.325616 & 1.02704 & 0.709556 & 0.451198 & 1.160754 \\
\hline BJDH-12 & 0.710594 & 0.349883 & 1.060477 & 0.71121 & 0.365893 & 1.077103 \\
\hline BJDH-20 & 0.711819 & 0.449487 & 1.161306 & 0.706173 & 0.370602 & 1.076775 \\
\hline BARI-14 & 0.703127 & 0.575345 & 1.278472 & 0.71082 & 0.425061 & 1.135881 \\
\hline BARI-16 & 0.715644 & 0.386859 & 1.102503 & 0.712259 & 0.381305 & 1.093564 \\
\hline SE \pm & 0.038778 & 0.112077 & 0.155606 & 0.004771 & 0.154315 & 0.121301 \\
\hline
\end{tabular}

BARI-14 = BARI Sarisha-14, BARI-16 = BARI Sarisha-16

\section{Yield and yield components}

Effect of sowing dates

Sowing dates induced temperatures variability showed significant influence on yield and yield components (Table 2). Plant height of December 20 sowing was significantly higher than that of November 20 sowing while the reverse results were observed in other parameters. Significantly higher number of siliquae/plant, seeds/siliqua was observed in November 20 sowing compared to December 20 sowing. Seed size reduced significantly in December 20 sowing compared to November 20 sowing. Significant yield reduction was observed due to sowing date induced high temperature stress. Chauhan et al. (2009) also reported yield reduction due to temperature stress in Indian mustard. Aksouh et al. (2001) reported that heat stresses reduced the number of siliquaper plant, number of seeds per siliqua, and 1000-seed weight.

\section{Effect of genotypes}


Ahmed et al.

Genotypes showed significant variability in all the characters (Table 3). The maximum plant height was observed in BJDH-12 which was identical with BJDH-11, BJDH-20 and BARI Sarisha-16 but significantly higher than BARI Sarisha-14. The maximum number of branches/plant was found in BARI Sarisha14 which was identical with BJDH-11 but significantly higher than other genotypes. Among the genotypes, significantly highest number of siliqua/plant (207.38) was recorded in BJDH-11.The second highest siliqua/plant (156.54) was observed in BARI Sarisha-16 which was identical with BJDH-20 and BJDH-12 but significantly higher than BARI Sarisha-14. The highest number of seeds/siliqua (36) was found in BARI Sarisha-14 which was significantly higher than other genotypes. The second highest seeds/siliqua (15) was found in BARI Sarisha-16 which was significantly higher than other genotypes. The lowest seeds/siliqua was recorded in BJDH-12 which was identical with BJDH-11 and $\mathrm{BJDH}-12$. The highest 1000-seed weight was recorded in BJDH-20 which was significantly higher than other genotypes. The second highest 1000-seed weight was found in BJDH-12 which was significantly higher than others. The lowest 1000-seed weight was found in BARI Sarisha-14. The highest seed yield was observed in BJDH-11 which was significantly higher than other genotypes. The second highest seed yield was recorded in BJDH-20 which was identical with other genotypes and the lowest seed yield in BARI Sarisha -14 .

Table 2. Effect of sowing dates on yield and yield contributing characters of rapeseed-mustard (2017-18)

\begin{tabular}{|l|l|l|l|l|l|l|}
\hline $\begin{array}{l}\text { Sowing } \\
\text { Date }\end{array}$ & $\begin{array}{l}\text { Plant } \\
\text { height } \\
\text { (cm) }\end{array}$ & $\begin{array}{l}\text { Branches/ } \\
\text { plant (No.) }\end{array}$ & $\begin{array}{l}\text { Siliqua/ } \\
\text { plant (No.) }\end{array}$ & $\begin{array}{l}\text { Seeds/ } \\
\text { siliqua } \\
\text { (No.) }\end{array}$ & $\begin{array}{l}\text { 1000-seed } \\
\text { wt. (g) }\end{array}$ & $\begin{array}{l}\text { Seed } \\
\text { yield/plant (g) }\end{array}$ \\
\hline Nov-20 & 125.00 & 5.65 & 156.15 & 18.58 & 4.05 & 6.20 \\
\hline Dec-20 & 140.35 & 4.70 & 138.10 & 17.20 & 3.46 & 4.50 \\
\hline LSD (0.05) & 6.55 & 0.46 & 12.41 & 1.22 & 0.20 & 0.45 \\
\hline CV(\%) & 7.60 & 11.53 & 10.67 & 10.50 & 8.10 & 10.11 \\
\hline
\end{tabular}

Table 3. Effect of genotypes on yield and yield contributing characters of rapeseed-mustard (2017-18)

\begin{tabular}{|l|l|l|l|l|l|l|}
\hline Genotype & $\begin{array}{l}\text { Plant height } \\
(\mathrm{cm})\end{array}$ & $\begin{array}{l}\text { Branches/ } \\
\text { plant } \\
\text { (No.) }\end{array}$ & $\begin{array}{l}\text { Siliqua/ } \\
\text { plant (No.) }\end{array}$ & $\begin{array}{l}\text { Seeds/ } \\
\text { siliqua } \\
\text { (No.) }\end{array}$ & $\begin{array}{l}1000 \text {-seed } \\
\text { weight (g) }\end{array}$ & $\begin{array}{l}\text { Seed yield/ } \\
\text { plant (g) }\end{array}$ \\
\hline BJDH-11 & 142.25 & 6.00 & 207.38 & 13.00 & 3.54 & 6.27 \\
\hline BJDH-12 & 149.13 & 5.00 & 153.71 & 13.00 & 3.94 & 5.05 \\
\hline BJDH-20 & 141.63 & 4.00 & 155.00 & 12.00 & 4.36 & 5.37 \\
\hline BARI-14 & 90.13 & 6.00 & 63.00 & 36.00 & 3.28 & 4.70 \\
\hline BARI-16 & 140.25 & 5.00 & 156.54 & 15.00 & 3.65 & 5.36 \\
\hline LSD (0.05) & 10.36 & 0.72 & 19.62 & 1.93 & 0.31 & 0.71 \\
\hline CV (\%) & 7.60 & 11.53 & 10.67 & 10.50 & 8.10 & 10.11 \\
\hline
\end{tabular}

\section{Conclusion}

On the basis of physiological parameters, antioxidant activity and seed yield, the mustard genotype, BJDH-11 and BJDH-20 could be selected as terminal high temperature ( 3 to $4{ }^{\circ} \mathrm{C}$ higher than average temperature)tolerant genotypes.

\section{References}


55

Aggarwal, P.K. and R.K. Mall. 2002. Climate change and rice yields in diverse agro-environments of India. II, Effect of uncertainties in scenario and crop models on impact assessment. Climate Change 52: 331-343.

Aksouh, N.M., B.C. Jacobs, F.L. Stoddard and R.J. Mailer. 2001. Response of canola to different heat stresses. Aust. J. Agric. Res. 2001. 52: 817824.

Arnon, D. 1949. Copper enzyme in isolated chloroplast and poly phenol oxidase in Beta vulgaris. Plant Physiol. 24: 1-7.

Babita Rani, N. Kumari, Pooja, V. Jain, K. Dhawan, Monika, R. Avtar, A. Kumar and P. Sheoran. 2016. Antioxidative System as Influenced by High Temperature stress in Brassica juncea. Current Trends in Biotechnology and Pharmacy. 10(2): 118-125.

Bradford, M.M. 1976. A rapid and sensitive method for the quantitation of microgram quantities of protein utilizing the principle of protein-dye binding. Analytical Biochemi. 72: 248-254.

Chauhan, J.S., M.L. Meena, M. Saini, D.R. Meena, M. Singh, S.S. Meena and K.H. Singh. 2009. Heat stress effects on morpho-physiological characters of Indian mustard (Brassica juncea L.). Paper presented in $16^{\text {th }}$ Australian Research Assembly on Brassicas. Ballarat, Victoria, Australia. September 14-16.

Hall, A.E. 1992. Breeding for heat tolerance. Plant Breeding rev. 10: 129-168.

Hayat, S.A. Masood, M. Yusuf, Q. Fariduddin, and A. Ahmad. 2009. Growth of Indian mustard (Brassica juncea L.) in response to salicylic acid under high-temperature stress. Braz. J. Plant Physiol. 21(3): 187-195.

Hemeda, H.M. and B.P. Klein. 1990. Effects of naturally occurring antioxidants on peroxidase activity of vegetable extracts. J. Food Sci. 55: 184-185.

Hodges, D.M., J.M. DeLong, C.F. Forney and R.K. Prange. 1999. Improving the thiobarbituric acid-reactive- substances assay for estimating lipid peroxidation in plant tissues containing anthocyanin and other interfering compounds. Planta 207: 604-611.

Hossain, M.A., M. Hasanuzzaman and M. Fujita. 2010. Up-regulation of antioxidant and glyoxalase systems by exogenous glycinebetaine and proline in mungbean confer tolerance to cadmium stress. Physiol. Molecular Biol. Plants. 16: 259-272.

Moradshahi, A., B. Salehi Eskandari and B. Kholdebarin. 2004. Some physiological responses of canola (Brassica napus L.). Iranian J. Sci. Tech. Trans. A- Sci., 28, pp.43-50 (in Persian).

Nakano, Y. and K. Asada. 1981. Hydrogen peroxide is scavenged by ascorbatespecific peroxidase in spinach chloroplasts. Plant Cell Physiol. 22: 867880.

Singh, M., S.S. Rathore and P. Raja. 2014. Physiological and Stress Studies of Different Rapeseed-Mustard Genotypes under Terminal Heat Stress. Int. J. Genetic Eng. Biotech. 5(2): 133-142.

Soengas, P.V.M. Rodrhguez, P. Velasco and M.E. Cartea. 2018. Effect of Temperature Stress on Antioxidant Defenses in Brassica oleracea. ACS Omega. 3: 5237-5243. 
56

Ahmed et al.

Wassmann, R., S.V.K. Jagadish, K. Sumfleth, H. Pathak, G. Howell, A. Ismail, R. Serraj, E. Redona, R.K. Singh and S. Heuer. 2009. Regional vulnerability of climate change impacts on Asian rice production and scope for adaptation. Advn. Agron. 102: 91-133.

Wilson, R.A., M.K. Sangha, S.S. Banga, A.K. Atwal and S. Gupta. 2014. Heat stress tolerance in relation to oxidative stress and antioxidants in Brassica juncea. J. Environ. Biol. 35(2): 383-387.

Xu, S., Li, J., X. Zhang, H. Wei and L. Cui. 2006. Effect of heat acclimation pretreatmenton changes of membrane lipid peroxidation, antioxidant metabolites, and ultra-structure of chloroplasts in two cool-season turf grass species under heat stress. Environ. Expt. Bot. 56: 264-285. 